\title{
Physiology of Sugarcane Under Water Stress: Invertase, ATP-ase and Amylase Behavior in Plants Experiencing Water Deficiency, Night Flooding and Continuous Flooding'
}

\author{
Alex G. Alexander, George Samuels, Gene L. Spain, and \\ Rafael Montalvo-Zapata ${ }^{2}$
}

\section{INTRODUCTION}

Although controlled water supply has long been a means of promoting sugarcane growth and ripening, there is a paucity of information relating to biochemical changes as the cane plant passes from one water regime to another. As a rule, ample water increases growth and tonnage while water restriction favors sucrose accumulation. These responses are essentially empirical; they tell us little about the partial processes of sugar synthesis, translocation, and storage. Much of our basic understanding of water roles in cane ripening is based upon the pioneer studies of Hartt $(19,20,21)$ performed in Hawaii several decades before photosynthetic and sugar accumulation mechanims were correctly sketched in sugarcane. More recent findings by Hartt (22) suggest that low water limits photosynthesis and sugar transport, but less so than it limits inversion and growth processes, so that ripening is incidental to major physiological restrictions.

Sugarcane responses to excessive water are also known mainly in empirical terms. Throughout the sugarcane world inherently productive soils are rendered problematic by inadequate drainage. Although soil acidity can sometimes be corrected with amendments, and soil aeration will improve with installation of drainage systems, the biochemical changes associated with excessive water remain unclear and without immediate remedy. Still more elusive are the effects of temporary flooding. Heavy rainfall can saturate the root profile from one to several days even when soil properties and drainage designs are faultless. Sugarcane raised on flood plains may be inundated occasionally for short periods. In such instances there are no outward manifestations to gauge the extent of water injury. It follows that a broader understanding of water physiology is necessary to attain the best possible management of water in sugar production.

In recent years much attention has been given to three kinds of hydrolytic

1 Submitted to the Editorial Board September 23, 1971.

2 Plant Physiologist, Agronomist, Associate Agronomist, and Assistant Chemist, respectively, Agricultural Experiment Station, Mayagüez Campus, University of Puerto Rico, Río Piedras, P.R. 
enzymes in sugarcane: Invertases, amylases, and adenosine triphosphatases (ATP-ases). Each group includes at least two distinct enzymes and all employ elements of water in reactions indispensable to growth and development. The present paper deals with their behavior in sugarcane subjected to water deficiency, temporary water excesses, and prolonged flooding.

\section{MATERIALS AND METHODS}

\section{GROWTH, TREATMENT AND HARVEST OF PLANT MATERIALS}

Two greenhouse experiments were conducted simultaneously with the interspecific variety P.R. 980 grown in sand culture. Treatments for the first experiment included water deficiency, normal water, night flooding, and continuous flooding. In the second experiment, comprising identical water variables, the cane plants were pretreated with gibberellic acid (GA). Earlier work (7) was suggestive that GA increased the efficiency of water utilization. Inconsistent field results with GA in Australia (32) have been attributed in part to uncontrolled water variables.

The sand culture technique employed has been described in detail (1). A moderately fine quartz sand, "silica shot", about No. 20 mesh, was washed in $0.01 \mathrm{~N} \mathrm{HCl}$, leached with tapwater and placed in 2-gallon glazed containers fitted with glass wool over the drainage outlet. Ten to twelve one-eye cuttings were planted in each container. Seedlings were irrigated daily for 4 weeks without nutrient supplements. Thereafter, each container received one liter of tapwater at 7:30 a.m. and one liter of nutrient solution at 1:30 p.m. Nutrient concentrations (meq./l) were as follows: $\mathrm{N}$ (as $\mathrm{NO}_{3}$ ), 10; $\mathrm{PO}_{4}, 6 ; \mathrm{K}, 5 ; \mathrm{Ca}, 3 ; \mathrm{Mg}, 2$; and $\mathrm{SO}_{4}, 2$. Micronutrient levels (p.p.m.) were: $\mathrm{B}, 0.05 ; \mathrm{Cu}, 0.02 ; \mathrm{Mn}, 0.50 ; \mathrm{Zn}, 0.05 ; \mathrm{Mo}, 0.01$; and $\mathrm{Fe}, 1.0$.

At 16 weeks of age, 64 containers were selected for uniformity and divided into two groups of 32 containers each. One group was sprayed with distilled water and the other with an aqueous GA solution containing 0.01 percent active GA (potassium salt). Tween 20 was used as wetting agent at the rate of $1.0 \mathrm{ml}$. per liter. Ten days after GA treatment, four water regimes were established within each group: (a) no water; (b) the control, i.e., 2 liters daily (at 7:30 a.m. and 1:30 p.m.); (c) 2 liters daily plus night flooding; and (d) continous flooding. Flood conditions were created by fitting a rubber stopper in the drainage outlet and filling the container with tapwater. Plants were then standing in about 3 inches of water. To achieve night flooding the stoppers were fitted each evening at 7:00 p.m. and removed at 7:00 a.m.; for continuous flooding the outlets remained stoppered and a small amount of water was added daily to compensate for transpiration and evaporation losses. 
Within each experiment the containers were arranged in completely randomized designs with four replicates of every treatment. Each container held five to seven uniform plants. Under these conditions, sugarcane plants usually fill the containers with a mass of roots after about 4 months of growth. The roots slow drainage and give the sand an increased waterretaining capacity; however, the current drainage was quite good, somewhat faster than that of a light sandy soil.

Initial plant samples were harvested a few minutes before water treatments were begun and harvests were repeated at 2,5 and 9 days thereafter. Each sample consisted of four uniform plants per replicate cut at the sand surface. Immature storage tissue and the basal 14 inches of leaves +1 to +4 were frozen in a mixture of dry ice and acetone. They were later lyophilized and ground to a fine powder prior to the extraction of sugar and enzyme constituents. Leaf sheaths were weighed and oven-dried for moisture determinations. Millable stalks were ground with a small laboratory mill for Brix and polarization analyses.

\section{SUGAR AND ENZYME ANALYSES}

\section{Sugars}

Two $\mathrm{g}$. of leaf tissue, or $0.5 \mathrm{~g}$. of storage tissue, were placed in a $125 \mathrm{ml}$. flask containing $35 \mathrm{ml}$. of distilled water. The mixture was shaken mechanically for 1 hour at $22^{\circ} \mathrm{C}$. and most of the tissue debris was removed by expression through four layers of absorbent gauze. The extracts were centrifuged at 2,500 r.p.m. for 20 minutes. Samples of the clarified supernatant were withdrawn for sugar analysis and diluted $1: 10$ with $0.25 \mathrm{~N} \mathrm{NaOH}$. Total ketoses were measured colorimetrically by the resorcinol method of Roe (30). The sucrose fraction was determined similarly by the modification of Cardini et al. (17) in which fructose is first destroyed by heating samples for 15 minutes at $100^{\circ} \mathrm{C}$. in $0.20-0.25 \mathrm{~N} \mathrm{NaOH}$. Standard ketose curves were prepared from appropriate dilutions of a 0.10 -percent sucrose stock solution in saturated benzoic acid. Total reducing sugars were estimated by the dinitrosalicyclic acid technique of Sumner (33).

\section{Soluble Protein}

Protein was precipitated from clarified aqueous extracts by slow addition of solid ammonium sulfate, at $22^{\circ} \mathrm{C}$. and $\mathrm{pH} \mathrm{5.6}$. The 0 to 80 percent fraction was retained. Protein yield was increased by chilling samples to $4^{\circ} \mathrm{C}$. after all of the salt was added. Precipitated protein was removed with the centrifuge, redissolved in water, and dialyzed for 2 hours against two changes of distilled water. The protein solution was again clarified in the centrifuge and refrigerated at $4^{\circ} \mathrm{C}$. until needed for enzyme analyses. 
Protein content of appropriate dilutions was measured colorimetrically by the Folin-Ciocalteau method as modified by Sutherland et al. (34).

\section{Invertase}

Invertase was assayed in accordance with the amount of reducing sugar formed enzymatically in a buffered sucrose solution in 1 hour at $37^{\circ} \mathrm{C}$. and $\mathrm{pH}$ 5.5. The standard digest was composed as follows: $1.0 \mathrm{ml}$ of $0.10 \mathrm{M}$ sodium acetate-acetic acid buffer, $0.5 \mathrm{ml}$. of 2-percent sucrose solution, and $0.5 \mathrm{ml}$. of enzyme preparation from immature storage tissue. Control vessels received distilled water in place of enzyme. The reaction was terminated with $1.0 \mathrm{ml}$. of dinitro reagent (33), and reducing sugar was determined following color development at $100^{\circ} \mathrm{C}$. Appropriate glucose dilutions served as the reducing sugar standard curve. The activity unit was arbitrarily defined as the amount of enzyme producing $0.10 \mathrm{mg}$. of reducing sugar in 1 hour at $37^{\circ} \mathrm{C}$. under standard conditions of the assay. Invertase action was computed and recorded as specific activity (activity units per mg. of protein).

\section{Adenosine Triphosphatase (ATP-ase)}

The assay for ATP-ase was based upon the amount of inorganic phosphorus enzymatically released from $0.015 \mathrm{M}$ ATP in $0.10 \mathrm{M}$ sodium acetate acid buffer, $\mathrm{pH} 5.5$, in 30 minutes at $37^{\circ} \mathrm{C}$. Final volume of the enzymesubstrate solution was $2.0 \mathrm{ml}$. The reaction was terminated with $1.0 \mathrm{ml}$. of 10-percent trichloroacetic acid. Phosphorus was measured by the phosphomolybdic acid method (26). The activity unit is defined as the amount of enzyme catalyzing the hydrolysis of $0.01 \mathrm{mg}$. of phosphorus in 30 minutes under standard conditions of the assay. ATP-ase action was computed and recorded as specific activity.

\section{Amylase}

The amylase assay was very similar to that of invertase with the exception that a 2-percent solution of soluble potato starch served as substrate, and the assay was conducted with enzyme preparations from both leaf and immature storage tissues. The reaction was run for 1 hour at pH 5.5 and $37^{\circ}$ C. Reducing sugar was determined colorimetrically employing a standard curve developed with appropriate maltose solutions. Amylase action was also computed and recorded as specific activity.

All data collected by replicates were subjected to statistical analysis of variance, and paired means were analyzed by Student's T-test. Pol values were derived from combined stalk samples and are treated empirically in the text. 


\section{RESULTS AND DISCUSSION}

VISUAI SYMPTOMS OF WATER DEFICIENCY AND TOXICITY

Cloudy and cool weather prevailed during the first 3 days of treatment and no visible symptoms were noted other than slight wilting within the low-water regime. Typical drought symptoms developed under normal sunlight on the fourth day. Spindle leaves became very tightly curled. Discoloration (yellowing) developed in the oldest leaves and leaf sheaths, becoming general throughout leaves +3 to +6 on the fifth day. Leaf tips and sheaths appeared to desiccate and discolor more readily than the blade lamina tissue. Severe desiccation and defoliation was general by the ninth day. Somewhat surprising was the appearance of virtually identical symptoms in the low-water and continously flooded plants. Initial symptoms appeared about a day later among the flooded cane, but thereafter a genrrally parallel development was observed. Figure 1 illustrates the similarity of symptoms among water-deficient and continuously flooded plants.

Unlike water-deficient plants, the flooded cane developed whorls of adventitious roots extending outward and downward from submerged nodes (fig. 2). Secondary growth extended upward from the surface of these roots. Significance of the root initiation and phototropic growth is not immediately clear. However, exclusion of atmospheric oxygen from root zones in sand culture ordinarily causes death of the roots. At the close of the study, eximination of flooded root zones revealed a deep bluish discoloration of extrerior roots and the entire root mass produced an odor of hydrogen sulfide. Adventitious roots remained healthy (fig. 2), possibly because they were exposed to light. No visual symptoms were observed in night-flooded sugarcane.

Prior treatment of plants with GA appeared to delay the development of desiceative symptoms among the low-water and continous-flooding regimes. The (iA-treated plants remained green and apparently healthy at the 5-day harvest. However, at 9 dilys there were no discernible differenees between (iA and non-GA plants.

\section{GROWTH AND SUGAR RESPONSES}

Sheath moisture values at 9 days reflected the desiceation observed visually among water-deficient and water-toxic (table 1). Neither the 2-liter treatment nor night-flooding calused appreciable changes in sheath moisture pereentages. Plants pretreated with GA also lost moisture in the continuousflooding and low-water regimes.

liigure 3, illustrating sheath moisture levels at each harvest, shows that major water losises oceurred carlier among plants having restricted water supply thatn among those given excessive water. After the fifth day flooded 
TABLE 1.-Sheath-moisture values for sugarcane supplied with variable waler in sand culture and pretreated with variable $G A^{1}$

\begin{tabular}{|c|c|c|c|c|c|c|}
\hline \multirow{2}{*}{ Experiment number } & \multirow{2}{*}{$\begin{array}{l}\text { Treat- } \\
\text { ment } \\
\text { period } \\
\text { (days) }\end{array}$} & \multicolumn{5}{|c|}{ Daily water supply } \\
\hline & & None & $\begin{array}{l}2 \text { liters } \\
\text { (control) }\end{array}$ & $\begin{array}{l}2 \text { liters plus } \\
\text { night flood }\end{array}$ & $\begin{array}{l}\text { Continuous } \\
\text { flood }\end{array}$ & Mean \\
\hline & & \multicolumn{5}{|c|}{ Sheath moisture (parcent) } \\
\hline \multirow[t]{2}{*}{ 1. $(\mathrm{GA}-0)$} & 0 & 82.4 & 82.7 & 81.9 & 82.3 & 82.3 \\
\hline & 9 & 77.1 & 82.8 & 80.5 & 76.6 & 79.3 \\
\hline \multirow[t]{2}{*}{ 2. $(\mathrm{GA}-0.01 \%)$} & 0 & 82.3 & 83.0 & 82.9 & 83.2 & 82.9 \\
\hline & 9 & 75.4 & 81.5 & 81.5 & 75.6 & 78.5 \\
\hline
\end{tabular}

1 Each figure is the computed mean of four replicates. Leaf sheaths $(+1$ to +4$)$ were harvested from four plants in each replicate.

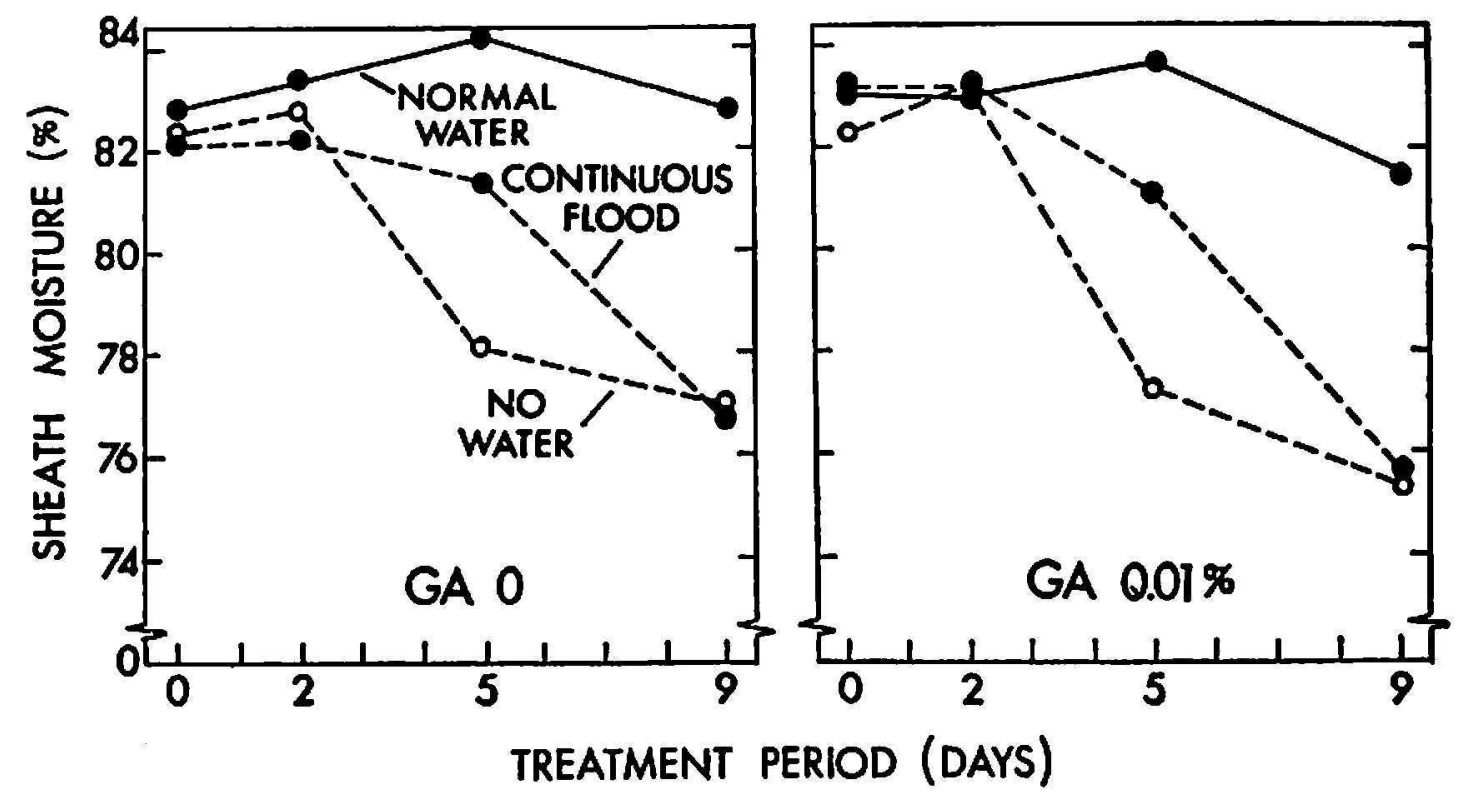

FrG. 3.-Sheath moisture changes for sugarcane supplied with variable water in sand culture. Nine days of treatment produced almost identical drying effects in water-deficient and continuously-flooded plants.

plants lost moisture more rapidly. This response was consistent for both the GA and non-GA experiments.

Under field conditions prolonged water deficiency is more apt to occur than extended flooding; however, in an academic sense it is significant that inadequate water and excessive water produced identical outward manifestations. In this connection it is of interest to learn whether the traditional effects of restricted water supply, including growth reduction and ripening, are also produced by excessive water.

The short duration of these experiments did not permit major growth changes and only small green-weight increases were evident by the ninth day (table 2), primarily within the GA-treated experiment. Although none of the green-weight changes were significant statistically, it appears that 
fresh weights increased in continuously flooded plants treated with GA, whereas the flooding treatment was restrictive against weight increases in the GA-free experiment. This is tacit support for the hypothesis that GA facilitates water uptake in sugarcane (7).

In both experiments leaf sucrose declined sigificantly among waterdeficient plants after the second day (table 3 ). A similar but less pronounced trend occurred in continuously flooded plants. In neither case did GA pretreatment alter the sucrose decline. Hartt (22) attached strong significance to water roles in photosynthesis and sugar transport, and maintained that

TABLE 2.-Green weights of immature sugarcane supplied with variable waler in sand cullure and prelrealed with variable $G A^{2}$

\begin{tabular}{|c|c|c|c|c|c|c|}
\hline \multirow{2}{*}{ Experiment number } & \multirow{2}{*}{ Daily water supply (liters) } & \multicolumn{4}{|c|}{ Days treated } & \multirow{2}{*}{ Mear } \\
\hline & & 0 & 2 & 5 & 9 & \\
\hline & & \multicolumn{4}{|c|}{ 8. pes plant } & \\
\hline \multirow[t]{5}{*}{ 1. $(\mathrm{GA}-0)$} & 0 & 231 & 240 & 220 & 226 & 226 \\
\hline & 2 (control) & 220 & 220 & 217 & 238 & 224 \\
\hline & $2+$ night flooding & 217 & 238 & 269 & 255 & 243 \\
\hline & Continuous flooding & 241 & 282 & 263 & 206 & 248 \\
\hline & Mean & 227 & 248 & 239 & 228 & 236 \\
\hline \multirow[t]{5}{*}{ 2. $(\mathrm{GA}-0.01 \%)$} & 0 & 262 & 277 & 335 & 248 & 293 \\
\hline & 2 (control) & 275 & 298 & 297 & 302 & 293 \\
\hline & $2+$ night flooding & 258 & 268 & 261 & 329 & 279 \\
\hline & Continuous flooding & 250 & 271 & 295 & 335 & 283 \\
\hline & Mean & 273 & 279 & 297 & 304 & 287 \\
\hline
\end{tabular}

1 Each figure is the computed mean of four replicates. From each replicate four uniform plants were cut at the sand surface and weighed immediately.

sugar may accumulate even after photosynthesis is impaired by insufficient water. In the present study all plants experienced a sucrose decline in immature storage tissue during the first 48 hours; thereafter, sucrose accumulated in the low-water and excessive-water regimes (table 4). This suggests that foliar sucrose was depleted as a result of increased sucrose translocation rather than repressed photosynthesis.

Although very little mature stalk tissue was available and no statistical analyses were performed on juice-quality data, there appeared to be several important effects of water and GA treatments: (a)Where no GA was given, all water regimes produced moderate polarization increases with the exception of continuous flooding. The latter treatment caused major polarization decline (table 5). (b) Pretreatment with GA completely eliminated 
TABLE 3.-Leaf sucrose content of sugarcane supplied with variable water in sand culture and pretreated with variable $G A^{1}$

\begin{tabular}{|c|c|c|c|c|c|c|}
\hline \multirow{2}{*}{$\begin{array}{l}\text { Experiment } \\
\text { number }\end{array}$} & \multirow{2}{*}{$\begin{array}{l}\text { Daily water } \\
\text { supply (liters) }\end{array}$} & \multicolumn{4}{|c|}{ Treatment period (days) } & \multirow{2}{*}{ Mean } \\
\hline & & 0 & 2 & 5 & 9 & \\
\hline \multirow{3}{*}{ 1. $(\mathrm{GA}-0)$} & & \multicolumn{4}{|c|}{ mg./g. of tissue } & \\
\hline & $\begin{array}{l}0 \\
2 \text { (control } \\
2+\text { night flooding } \\
\text { Continuous flooding }\end{array}$ & $\begin{array}{l}48.1 \\
50.7 \\
53.8 \\
54.7\end{array}$ & $\begin{array}{l}44.8 \\
35.9 \\
40.9 \\
43.1\end{array}$ & $\begin{array}{l}15.4^{* *} \\
27.2 \\
29.7 \\
29.7\end{array}$ & $\begin{array}{l}8.7^{* *} \\
35.4 \\
44.4 \\
31.7\end{array}$ & $\begin{array}{l}29.3 \\
37.3 \\
42.2 \\
39.8\end{array}$ \\
\hline & Mean & 51.8 & 41.2 & 25.5 & 30.1 & 37.2 \\
\hline 2. (GA-0.01\%) & $\begin{array}{l}0 \\
2 \text { (control) } \\
2+\text { night flooding } \\
\text { Continuous flooding }\end{array}$ & $\begin{array}{l}46.1 \\
44.6 \\
51.1^{*} \\
46.1\end{array}$ & $\begin{array}{l}33.0 \\
34.3 \\
37.9 \\
40.3\end{array}$ & $\begin{array}{l}15.9^{* *} \\
35.1 \\
39.5 \\
30.8\end{array}$ & $\begin{array}{l}11.8^{* *} \\
42.1 \\
49.3 \\
23.4^{* *}\end{array}$ & $\begin{array}{l}26.7 \\
39.0 \\
44.5 \\
35.2\end{array}$ \\
\hline & Mean & 47.0 & 36.4 & 30.3 & 31.7 & 36.4 \\
\hline
\end{tabular}

${ }^{1}$ Each figure is the computed mean of four replicates.

* Deviation from control is significant at the 5-percent level.

** Deviation from control is significant at the 1-percent level.

TABLE 4.-Sucrose content of immalure slorage tissue from sugarcane supplied with variable water in sand culture and prelreated with variable $G A^{1}$

\begin{tabular}{|c|c|c|c|c|c|c|}
\hline \multirow{2}{*}{$\begin{array}{c}\text { Experiment } \\
\text { number }\end{array}$} & \multirow{2}{*}{ Daily water supply (liters) } & \multicolumn{4}{|c|}{ Treatment period (days) } & \multirow{2}{*}{ Mean } \\
\hline & & 0 & 2 & 5 & 9 & \\
\hline \multirow{3}{*}{ 1. $(\mathrm{GA}-0)$} & & \multicolumn{4}{|c|}{ mg./s. of tissue } & \\
\hline & $\begin{array}{l}0 \\
2 \text { (control) } \\
2+\text { night flooding } \\
\text { Continuous flooding }\end{array}$ & $\begin{array}{l}68.1 \\
68.5 \\
76.8 \\
82.4\end{array}$ & $\begin{array}{l}27.9 \\
19.7 \\
32.3 \\
32.6\end{array}$ & $\begin{array}{l}67.9^{* *} \\
21.9 \\
34.8^{*} \\
40.8\end{array}$ & $\begin{array}{l}68.1 \\
43.9 \\
59.7 \\
89.3^{* *}\end{array}$ & $\begin{array}{l}63.8 \\
38.5 \\
50.9 \\
61.3\end{array}$ \\
\hline & Mean & 74.0 & 28.1 & 41.4 & 71.1 & 53.6 \\
\hline 2. (GA-0.01\%) & $\begin{array}{l}0 \\
2 \text { (control) } \\
2+\text { night flooding } \\
\text { Continuous flooding }\end{array}$ & $\begin{array}{l}78.8 \\
82.2 \\
74.9 \\
68.6\end{array}$ & $\begin{array}{l}35.7 \\
41.4 \\
34.4 \\
30.6\end{array}$ & $\begin{array}{l}39.3^{*} \\
24.3 \\
37.1 \\
35.4\end{array}$ & $\begin{array}{l}49.8 \\
36.3 \\
45.8 \\
60.0^{* *}\end{array}$ & $\begin{array}{l}50.9 \\
46.1 \\
48.1 \\
48.7\end{array}$ \\
\hline & Mean & 76.1 & 35.5 & 34.0 & 48.0 & 48.4 \\
\hline
\end{tabular}

1 Each figure is the computed mean of four replicates.

* Deviation from control is significant at the 5-percent level.

** Deviation from control is significant at the 1-percent level. 
the continuous flooding effect. Also evident was a general GA suppression of polarization values at both the 0 - and 9-day harvests. This is consistent with the expectation that GA was actively stimulating growth, and hence the remobilization of stored sugar for growth processes. Greenhouse studies (10) have shown that stored sucrose is lost as an early GA effect, and that increased sucrose storage can be expected as a long-term GA response.

A particularly severe sucrose loss occurred among the GA-treated cane given 2 liters of water daily (table 5). This was the control or "normal" water regime, the only treatment designed to produce no water stress of any kind, and GA appeared to be most effective here in diverting storage sugar for growth processes. The tendency for each of the three water-stress regimes to modify the hormone effect is suggestive that GA relates closely

TABLE 5.-Polarization values for milled sugarcane juice following variable water trealment of the plants in sand culture. Foliar GA pretreatments were applied 10 days before water variables were initiated ${ }^{1}$

\begin{tabular}{lcrrrrr}
\hline & Harvest & \multicolumn{5}{c}{ Daily water supply } \\
\cline { 3 - 7 } & $\begin{array}{c}\text { period } \\
\text { (days) }\end{array}$ & None & $\begin{array}{c}\text { 2 liters } \\
\text { (control) }\end{array}$ & $\begin{array}{c}\text { 2 liters plus } \\
\text { night flood }\end{array}$ & $\begin{array}{c}\text { Continuous } \\
\text { flood }\end{array}$ & Mean \\
\hline 1. (GA-0) & 0 & 13.8 & 13.8 & 16.2 & 17.8 & 15.4 \\
& 9 & 17.3 & 18.0 & 22.4 & 9.1 & 16.7 \\
2. (GA-0.01\%) & 0 & 10.5 & 9.9 & 12.3 & 10.6 & 10.8 \\
& 9 & 14.7 & 5.6 & 20.7 & 13.5 & 13.6 \\
\hline
\end{tabular}

1 Four stalks from each of the four replicates were composited and ground with a small laboratory mill. Aliquot juice samples were taken for pol analysis immediately following the sedimentation and filtration steps.

with water in storage processes as well as in sugar synthesis and translocation.

\section{ENZYME RESPONSES}

\section{Invertase}

The visual symptoms, growth data, and sugar data have all implied that insufficient water and excessive water produce similar reponses in sugarcane. The same conclusion can be drawn for invertase. Although none of the water variables had yet affected invertase at the 2-day harvest (table 6), the enzyme was greatly depressed at the fifth and ninth days among waterdeficient and continuously-flooded sugarcane (fig. 4). Moreover, while the GA pretreatment tended to suppress invertase among all water regimes the two extreme water treatments produced nearly identical invertase curves. On the other hand, no appreciable invertase changes were produced by any of the water variables until after the second day. The relative in- 
sensitivity of acid invertase to initial water changes, as compared to its pronounced sensitivity to light $(11,31)$, admittedly came as a surprise.

A significant result of this study is the implication that such widely diverse treatments as excessive and deficient water levels could have a common effect upon a hydrolytic enzyme. A frequent assumption among sugar growers is that the witholding of irrigation water promotes ripening by slowing down inversion. Quite possibly the same effect would be produced by flooding the sugarcane. Although the present evidence does not permit firm conclusions, it appears that invertase decline was an indirect

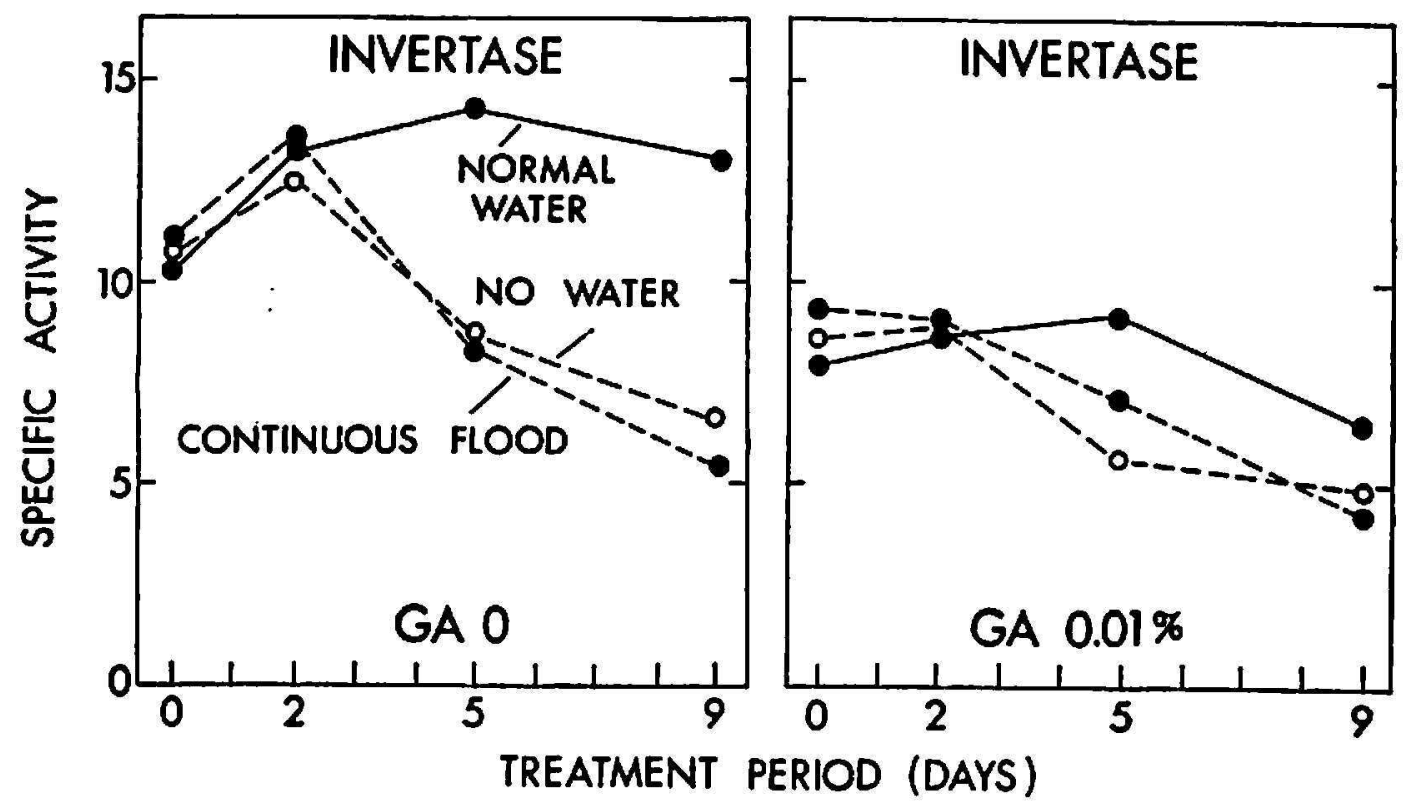

Fic. 4.-Invertase activity in immature storage tissue of sugarcane given variable water in sand culture. Left: Invertase decline in water-deficient and water-toxic plants. Right: Identical water treatments following pretreatment with GA. Note that GA generally suppressed invertase and eliminated much of the enzyme's differential among water regimes.

effect of the extreme water regimes rather than a direct action against the synthesis or stability of invertase m-RNA. In the latter instance an invertase response should have been recorded prior to the fifth day. Moreover, the large dosage of applied hormone might logically have alleviated an instability of m-RNA (18).

Earlier studies have revealed distinct diurnal shifts in invertase level, including a seven-fold decline between mid morning and late afternoon (11, 31). Although night flooding might logically induce atypical endogenous rhythms in a highly-sensitive enzyme synthesis mechanism, no significant effect was produced by night flooding on the sugarcane acid invertase (table 6).

The present study added little to our prior knowledge of invertase roles 
in growth and sugar accumulation. On the other hand, the general repression of invertase in the GA-treated plants is consistent with the findings of Glasziou, et al. (18) relative to a hormonal regulation system for sugarcane invertases. Present data also support the contention that acid invertase can be suppressed to about 35 percent of normal levels before it becomes a lifelimiting factor (8). This level was just beginning to be approached in waterdeficient and flooded cane when the study was terminated. One author (A.G.A.) has long felt that invertase levels per se can be useful screening

TaBLE 6.-Inverlase levels in immalure slorage lissue of sugarcane given variable water supply in sand culture. In the second experiment the plants were pretreated with foliar GA 10 days before waler variables were initiated ${ }^{3}$

\begin{tabular}{|c|c|c|c|c|c|c|}
\hline \multirow{2}{*}{$\begin{array}{c}\text { Experiment } \\
\text { number }\end{array}$} & \multirow{2}{*}{ Daily water supply (liters) } & \multicolumn{4}{|c|}{ Treatment period (days) } & \multirow{2}{*}{ Mean } \\
\hline & & 0 & 2 & 5 & 9 & \\
\hline \multirow{3}{*}{ 1. $(\mathrm{GA}-0)$} & & \multicolumn{4}{|c|}{ Speciffe actioily } & \\
\hline & $\begin{array}{l}0 \\
2 \text { (control) } \\
2+\text { night flooding } \\
\text { Continuous flooding }\end{array}$ & $\begin{array}{l}10.7 \\
10.2 \\
10.5 \\
11.1\end{array}$ & $\begin{array}{l}12.5 \\
13.3 \\
12.5 \\
13.7\end{array}$ & $\begin{array}{l}8.7^{* *} \\
14.3 \\
12.1 \\
8.6^{* *}\end{array}$ & $\begin{array}{l}6.6^{*} \\
13.0 \\
9.2 \\
5.4^{* *}\end{array}$ & $\begin{array}{r}9.6 \\
12.7 \\
11.1 \\
9.7\end{array}$ \\
\hline & Mean & 10.6 & 13.0 & 10.9 & 8.6 & 10.8 \\
\hline 2. (GA-0.01\%) & $\begin{array}{l}0 \\
2 \text { (control) } \\
2+\text { night flooding } \\
\text { Continuous flooding }\end{array}$ & $\begin{array}{l}8.6 \\
7.9 \\
7.5 \\
9.3\end{array}$ & $\begin{array}{l}8.9 \\
8.7 \\
7.4 \\
9.0\end{array}$ & $\begin{array}{l}5.6^{* *} \\
8.2 \\
7.8 \\
7.1^{*}\end{array}$ & $\begin{array}{l}4.9 \\
7.4 \\
4.8 \\
4.2^{*}\end{array}$ & $\begin{array}{l}7.0 \\
8.1 \\
6.9 \\
7.4\end{array}$ \\
\hline & Mean & 8.3 & 8.5 & 7.4 & 5.1 & 7.3 \\
\hline
\end{tabular}

1 Details of the invertase assay are given under MATERIALS AND METHODS. Each figure is the computed mean of four replicates.

criteria for sugarcane breeders when estimating sucrose potential of seedlings (3). Invertase does not seem to be a good criterion for estimating the water status of sugarcane.

\section{ATP-ase}

The importance of foliar ATP-ases in sugarcane is linked to their probable involvement in the photochemical reactions of photosynthesis whereby the solar energy of sunlight is converted to chemical energy or ATP. Petrack and Lipmann (28) were the first to note similarities common to photophosphorylation and photohydrolysis. It has been suggested that ATP-ase activity in chloroplasts represents a partial reaction in the mechanism of 
photophosphorylation, possibly a reversal of ATP synthesis $(14,24,28,29)$. Bennun and Avron (15) proposed that light-requiring ATP-ase shares part of the photophosphorylative energy-transport system. Findings by Petrack et al (29) with spinach chloroplasts suggest that part of the electron transport pathway is common both to synthesis and hydrolysis of ATP. At least three types of ATP-ases are recognized in chloroplasts: Light dependent $(13,14,25)$; light triggered but dark functional $(14,23,25)$; and an exclusively dark ATP-ase $(27,28,35)$. Evidence of light-dependent and dark

TABLE 7.-Leaf ATP-ase activity in sugarcane given variable water supply in sand culture. In the second experiment plants were pretreated with foliar GA 10 days before water variables were initiated ${ }^{2}$

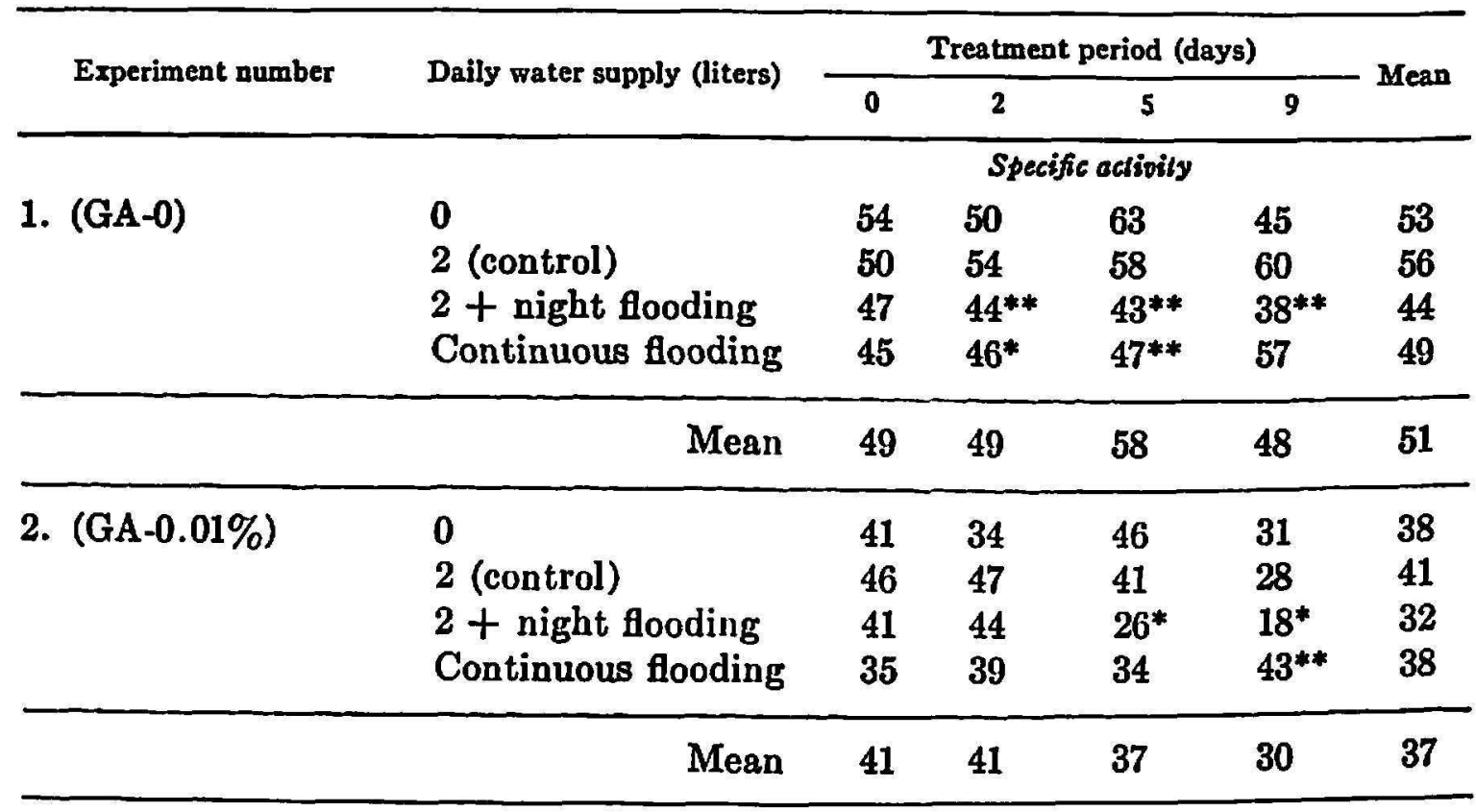

1 Each figure is the computed mean of four replicates. Details of the ATP-ase assay are given under MATERIALS AND METHODS.

* Deviation from control is significant at the 5-percent level.

** Deviation from control is significant at the 1-percent level.

ATP-ases in sugarcane leaves has been reported (11). The light-dependent sugarcane ATP-ase is sensitive to nitrogen status and virtually disappears in nitrogen-deficient plants (9).

Moreover, as is true of sugarcane acid invertase, foliar ATP-ase levels are quite sensitive to light $(9,11)$. However, unlike invertase, the two extreme water regimes did not produce a discrete response for ATP-ase (table 7). The only water regime consistently affecting ATP-ase was night flooding. The latter treatment repressed ATP-ase significantly by the second day in GA-free plants, and by the fifth day in the GA-treated plants. Because a similar trend was not found among continuously flooded cane, it is concluded that flooding in itself did not affect ATP-ase synthesis; rather, 
normal ATP-ase production must have relied on the stability of some daynight-day rhythm which was broken by night flooding. In this connection it would be instructive to examine individually night flooding effects on the light- and nitrogen-sensitive ATP-ases believed to be present in cane leaves (12). Behavior of the nitrogen $\left(\mathrm{NO}_{3}\right.$ )-sensitive ATP-ase during periodic flooding and the concurrent rate of $\mathrm{NO}_{3}$ reduction should be studied. The latter process, like ATP-ase, is very possibly linked to the rate of photosynthetic phosphorylation.

As was true of invertase, GA pretreatment generally suppressed ATP-ase among each of the water regimes (table 7). If one accepts for a moment the yet unproven role of ATP-ase in sugarcane photophosphorylation, the present GA response is additional evidence of GA activity in sugarcane photosynthesis. Previous evidence from GA-treated cane includes increased levels of foliar hexoses (9) and foliar sucrose $(4,5)$, increased storage sucrose (10), increased photosynthesis efficiency (16), and more effective recovery of photosynthesis upon reillumination of darkened leaves (9).

\section{Amylase}

The present results suggest that amylase synthesis is sensitive to water supply, but less so than invertase. Possibly as a result of clearer and warmer weather, amylase increased in control plants after the second day (table 8, experiment 1) while the amylase level in water-deficient plants remained constant. In continuously flooded plants the enzyme tended to increase but remained significantly below control levels at the fifth- and ninth-day harvests. Night flooding also imposed a partial restriction against the normal amylase increase. Pretreatment with GA generally lowered amylase action by the time water variables were initiated (table 8 , experiment 2 ). The fact that GA failed to increase amylase appreciably in water-deficient cane suggests that low water supply had not operated against a hormonal control system for amylase.

As previously noted $(2,6)$, there are striking similarities between sugarcane acid invertase and $\beta$-amylase with respect to physical and chemical properties. Some evidence points toward a common m-RNA factor for synthesis of the enzymes in immature storage tissue. However, in the present study neither water deficiency nor excess produced amylase restrictions of the magnitude found for invertase. It is therefore surmised that amylase is less sensitive to water regime than invertase, and that amylase can be synthesized by the plant under flood conditions prohibitive for invertase production.

\section{SUMMARY}

Effects of water stress on growth, sugar production and enzymology of sugarcane were evaluated in two greenhouse experiments in which sugarcane 
of the variety P.R. 980 was grown in sand culture with controlled nutrient supply. At 14 weeks of age, four water regimes were created for each of the two experiments: No water, normal water (2 liters daily), normal water plus night flooding, and continuous flooding. One experiment was pretreated with a 0.01-percent solution of active gibberellic acid (GA) 10 days before water variables were initiated. Samples of leaf, leaf sheath, immature storage tissue and stalk tissue were harvested at 0, 2, 5, and 9 days. Enzyme assays were conducted with leaf and immature storage tissue preparations for acid invertase, adenosine triphosphatase (ATP-ase), and $\beta$-amylase.

TABLE 8.-Leaf amylase activily in sugarcane given variable waler supply in sand culture. In the second experiment plants were pretreated with foliar $G A 10$ days before water variables were initiated ${ }^{2}$

\begin{tabular}{|c|c|c|c|c|c|c|}
\hline \multirow{2}{*}{ Experiment number } & \multirow{2}{*}{ Daily water supply (liters) } & \multicolumn{4}{|c|}{ Treatment period (days) } & \multirow{2}{*}{ Mean } \\
\hline & & 0 & 2 & 5 & 9 & \\
\hline & & \multicolumn{4}{|c|}{ Specific activity } & \\
\hline \multirow[t]{2}{*}{ 1. $(\mathrm{GA}-0)$} & $\begin{array}{l}0 \\
2 \text { (control) } \\
2+\text { night flooding } \\
\text { Continuous flooding }\end{array}$ & $\begin{array}{l}43 \\
43 \\
37 \\
42\end{array}$ & $\begin{array}{l}45 \\
51 \\
53 \\
58\end{array}$ & $\begin{array}{l}40^{* *} \\
75 \\
59^{*} \\
51^{* *}\end{array}$ & $\begin{array}{l}41^{* *} \\
60 \\
50^{*} \\
51^{*}\end{array}$ & $\begin{array}{l}42 \\
57 \\
50 \\
51\end{array}$ \\
\hline & Mean & 41 & 52 & 56 & 51 & 50 \\
\hline \multirow[t]{2}{*}{ 2. (GA-0.01\%) } & $\begin{array}{l}0 \\
2 \text { (control) } \\
2+\text { night flooding } \\
\text { Continuous flooding }\end{array}$ & $\begin{array}{l}39 \\
33 \\
27 \\
25\end{array}$ & $\begin{array}{l}35 \\
27 \\
26 \\
27\end{array}$ & $\begin{array}{l}36^{* *} \\
61 \\
48^{*} \\
55\end{array}$ & $\begin{array}{l}46 \\
58 \\
29 \\
51\end{array}$ & $\begin{array}{l}39 \\
45 \\
38 \\
40\end{array}$ \\
\hline & Mean & 31 & 29 & 50 & $\mathbf{5 1}$ & 41 \\
\hline
\end{tabular}

1 Each figure is the computed mean of four replicates. Details of the amylase assay are given under MATERIALS AND METHODS.

* Deviation from control is significant at the 5-percent level.

** Deviation from control is significant at the 1-percent level.

The following results were obtained:

1. Foliar symptoms appeared between the fifth and ninth day among the low-water and continuous flooding regimes. Wilting of leaves and leaf sheaths, yellowing of leaf tips, extensive yellowing of older leaves and leaf sheaths, and severe curling of spindle tissues was general among both treatments. Symptoms were delayed but not prevented by GA pretreatment. Normal water and night flooding produced no visible effects. Whorls of adventitious roots grew from submerged nodes of continuously flooded plants.

2. Sheath moisture values ultimately declined in water-deficient and 
water-toxic plants regardless of GA treatment. Continuously flooded plants increased total fresh weight, regardless of leaf and sheath desiccation, when pretreated with GA. A GA role in promoting water uptake is suggested.

3. Leaf sucrose declined in water-deficient and continuously flooded sugarcane but increased in immature storage tissues. This was taken as evidence of continued sucrose transport under moisture conditions restrictive against sugar synthesis. Polarization values for milled juice indicated that GA pretreatment caused a decline of storage sucrose under a normal water regime, but GA prevented storage sucrose losses under a regime of continuous flooding. The former GA effect is interpreted in terms of growth stimulation, the latter in terms of GA involvement in sugar accumulation processes effective in transport of sucrose to storage areas.

4. Invertase was suppressed both by deficient and excessive water regimes and by GA pretreatment. Night flooding produced little effect.

5. ATP-ase was strongly suppressed by night flooding but no consistent effects were produced by the other water regimes. The ATP-ase suppression by excessive night water was interpreted as a perturbation of normal diurnal-nocturnal rhythms rather than a sensitivity of synthesis mechanisms to flooding per se. GA pretreatment suppressed ATP-ase among all water regimes. Assuming that foliar ATP-ase is a functional entity of photosynthetic phosphorylation, the GA effect was taken as further evidence of a GA influence upon sugarcane photosynthesis.

6. Foliar amylase remained at a constant level in water-deficient cane, while other water regimes tended to increase the enzyme. Amylase was less sensitive to water regime than invertase and appeared to be synthesized under flood conditions highly repressive for invertase.

It is concluded that low- and high-water regimes tend to produce common effects upon the overall synthesis and utilization of sugar in the cane plant. Hormone level may affect the rate of sugar utilization within high and low water regimes without altering the outward manifestations of these regimes. Hydrolytic enzyme level is apparently affected indirectly by prolonged water stress or by perturbation of endogenous day-night rhythms. However, the enzymes measured were not sufficiently sensitive to changing water supply to serve as indicators of water status.

\section{RESUMEN}

En dos experimentos de invernadero se evaluaron los efectos de un régimen controlado de agua sobre el crecimiento, producción y enzimología de la caña de azucar, en los cuales la variedad de caña de azúcar P.R. 980 se cultivó en arena con un suministro controlado de los nutrimentos. A las 14 semanas de edad se establecieron cuatro regimenes de agua para cada uno de los experimentos: ausencia total de agua, suministro normal de agua (2 litros diarios), suministro normal de agua más inundación nocturna e inundación continua. Las plantas de uno de los experimentos fueron 
pretratadas con una solución de ácido giberélico activo al 0.01 por ciento 10 días antes de iniciarse la aplicación de las variables de agua. A los 2,5 y 9 días se cosecharon muestras de la hoja, yagua, tejido tierno y canuto de la caña. Se hicieron análisis de la invertasa ácida, la trifosfatasa de adenosina (ATP-asa) y la $\beta$-amilasa en extractos acuosos de la hoja y tejido tierno reservante.

Se lograron los siguientes resultados:

1. Al quinto y noveno día aparecieron síntomas foliares entre las plantas sometidas a los regimenes de poca agua e inundación continua. La marchitez de las hojas y yaguas, el amarillamiento de la punta de las hojas, una extensa amarillez en las hojas y yaguas viejas y un enroscamiento severo del cogollo fueron síntomas generales en ambos tratamientos. Se demoró pero no se evitó la aparición de los síntomas mediante el pretratamiento con AG. Los regimenes de suministro normal de agua e inundación nocturna no produjeron efectos visibles. De los nudos sumergidos crecieron verticilos de raíces adventicias en las plantas sometidas a una inundación continua.

2. Los valores de humedad en las yaguas descendieron en las plantas con deficiencia de agua independientemente del tratamiento que se les diera con AG. Las plantas expuestas a una inundación continua y pretratadas con AG aumentaron en peso fresco independientemente de la desecación de la hoja y la yagua. Se sugiere que el AG es un factor que promueve la absorción de agua.

3. El contenido de sacarosa en la hoja disminuyó, tanto en la caña con deficiencia de agua como la expuesta a una inundación continua pero aumentó en el tejido tierno reservante. Esto se interpretó como evidencia de un continuo transporte de la sacarosa bajo condiciones de humedad desfavorables a la sintesis de azúcar. Los valores de polarización para el guarapo de la caña molturable indicaron que el pretratamiento con AG causó una disminución del azúcar almacenada bajo un régimen normal de agua, aunque evitó pérdidas de la sacarosa almacenada bajo un régimen de inundación continua. El primer efecto del AG se interpretó en términos de un estímulo en el crecimiento y el último, en términos de una participación del AG en los procesos de acumulación de la sacarosa al ser transportada a áreas de almacenamiento.

4. La invertasa quedó reprimida tanto por regímenes de suministro excesivo y suministro deficiente de agua como por el pretratamiento con AG. La inundación nocturna tuvo muy poco efecto.

5. La ATP-asa se reprimió grandemente bajo un régimen de inundación nocturna pero no se observaron efectos consistentes producidos por los otros regímenes de agua. La represión de la ATP-asa mediante el exceso de agua durante la noche se interpretó como una perturbación de los ritmos normales del día y la noche, más que como expresión de sensibilidad de los mecanismos sintéticos a la inundación per se. El pretratamiento con AG reprimió la ATP-asa en todos los regímenes de agua. Suponiendo que la ATP-asa foliar es una entidad funcional de la fosforilación fotosintética, el efecto del AG se consideró como una evidencia adicional de la influencia que el AG ejerce sobre la fotosíntesis de la caña.

6. La amilasa foliar permaneció a un nivel constante en la caña que tuvo una deficiencia de agua mientras que los otros regímenes tendieron a aumentar la cantidad de enzima. La amilasa se mostró menos sensitiva a un régimen de agua que la invertasa y pareció sintetizarse bajo condiciones de inundación que son muy represivas para la invertasa.

Se concluye que tanto los régimenes altos como los bajos de agua tienden a producir los mismos efectos en la síntesis y la utilización del azúcar en la caña. El nivel de las hormonas puede afectar la tasa de utilización del azúcar en el caso de ambos regímenes 
sin alterar las manifestaciones exteriores de tales regímenes. El nivel de las enzimas hidrolíticas parece afectarse indirectamente por un prolongado régimen controlado de agua o por la perturbación de los ritmos endógenos del día y la noche. Sin embargo, las enzimas que se midieron no fueron lo suficientemente sensitivas a los cambios en el suministro de agua como para servir de indicadores respecto a la importancia del factor agua.

\section{LITERATURE CITED}

1. Alexander, A. G., Sucrose-enzyme relationships in immature sugarcane as affected by variable nitrate and potassium supplied in sand culture, J. Agr. Univ. P.R. 48 (3): 165-231, 1964.

2. - Hydrolytic proteins of sugarcane: Amylase, J. Agr. Univ. P.R. 49 (3): 308-24, 1965.

3. - Evaluation of sucrose-enzyme relationships among twelve Puerto Rico sugarcane varieties, J. Agr. Univ. P.R. 51 (1): 29-38, 1967.

4. - Interrelationships of gibberellic acid and nitrate in sugar production and enzyme activity of sugarcane, J. Agr. Univ. P.R. 52 (1): 19-28, 1968.

5. - - Effects of combined silicon and gibberellic acid on enzyme behavior and sucrose content of immature sugarcane, Proc. Int. Soc. Sugarcane Technol. 13: 522-31, 1969.

6. - Comparative studies of yeast and sugarcane invertase, J. Agr. Univ. P.R. 53 (1) : 41-56, 1969.

7. - Relationships of gibberellic acid to water and phosphorus in the growth, sugar production, and enzyme behavior of sugarcane, J. Agr. Univ. P.R. $53(3): 149-66,1969$.

8. - The use of chemicals for sucrose control in sugarcane, Sugar y Azúcar, 64 (2): 21-25, 1969.

9. Alexander, A. G., Kumar, A., Montalvo-Zapata, R., and Spain, Gene L., Response of sugarcane enzymes to variable light: Variable illumination studies of invertase, ATP-ase, and amylase in plants experiencing nitrate-and gibberellic acid-induced stress, J. Agr. Univ. P.R. 54 (3): 448-76, 1970.

10. Alexander, A. G., Montalvo-Zapata, R., and Ashok Kumar, Gibberellic acid activity in sugarcane as a function of the number and frequency of applications, J. Agr. Univ. P.R. 54 (3) : 477-503.

11. Alexander, A. G., and Montalvo-Zapata, R., Relationships of light to enzyme and sucrose transformations in sugarcane treated with Paraquat, J. Agr. Univ. P. R. 54 (2): 246-96, 1970.

12. - Light- and nitrogen-sensitive adenosine triphosphatases in sugarcane leaves, Proc. Int. Soc. Sugarcane Technol. (In press).

13. Avron, M., Light-dependent adenosine triphosphatase in chloroplasts, J. Biol. Chem. 237 (6) : 2011-2017, 1962.

14. Bennun, A., and Avron, M., Light-dependent and light-triggered adenosine triphosphatases in chloroplasts, Biochem. Biophys. Acta 79: 646-48, 1964.

15. - The relation of light-dependent and light-triggered adenosine triphosphatases to photophosphorylation, Biochem. Biophys. Acta 109: 117-27, 1965.

16. Bull, T. A., The effects of temperature, variety, and age on the response of Saccharum spp. to applied gibberellic acid, Aust. J. Agr. Res. 15: 77-84, 1964.

17. Cardini, C. E., Leloir, L. F., and Chiriboga, J., The biosynthesis of sucrose, J. Biol. Chem. 214 : 149-55, 1955.

18. Glasziou, K. T., Gayler, K. R., and Waldon, J. C., Effects of auxin and gibberellic 
acid on the regulation of enzyme synthesis in sugarcane stem tissue. In: Biochemistry and Physiology of Plant Growth Substances. (Proc. 6th Int. Conf. on Plant Growth Substances). F. Wightman and C. Setterfield (Eds.), Runge Press, Ottawa, 1968.

19. Hartt, C. E., Water and cane ripening, Haw. Plant. Rec. 38: 193-206, 1934.

20. - Further notes on water and cane ripening. Haw. Plant. Rec. 40: 355-81, 1936.

21. - The third study of water and cane ripening, Haw. Plant. Rec. 43: 145-58, 1939.

22. - Effect of moisture supply upon translocation and storage of ${ }^{14} \mathrm{C}$ in sugarcane, Plant Physiol. 42: 338-46, 1967.

23. Hoch, G., and Martin, I., Photo-potentiation of adenosine triphosphate hydrolysis, Biochem. Biophys. Res. Commun. 12 (3) : 223-28, 1963.

24. Jagendorf, A. T., and Uribe, E. G., Photophosphorylation and the chemiosmotic hypothesis. Brookhaven Symp. Biol. 19: 215-45, 1962.

25. Marchant, R. H., and Packer, $L_{\text {., }}$ Light and dark stages in the hydrolysis of adenosine triphosphate by chloroplasts, Biochem. Biophys. Acta 75: 458-60, 1863.

26. Methods of Analysis of the Association of Official Agricultural Chemists, 6th ed., Washington, D. C., pp. 127-8, 1945.

27. Packer, I., and Marchant, R. H., Action of adenosine triphosphate on chloroplast structure, J. Biol. Chem. 239: 2061-2069, 1964.

28. Petrack, B., and Lipmann, F., in: McElroy, W. D., and Glass, H. B., (Eds.), Light and Life. Johns Hopkins Press, Baltimore, p. 621, 1961.

29. Petrack, B., Crastron, A., Sheppy, F., and Farron, F., Studies on the hydrolysis of adenosine triphosphate by spinach chloroplasts, J. Biol. Chem. 240 (2): 906-14, 1965.

30. Roe, J. H., A colorimetric method for the determination of fructose in blood and urine, J. Biol. Chem. 107: 15-22, 1934.

31. Slack, C. R., The physiology of sugarcane. VIII. Diurnal fluctuations in the activity of soluble invertase in elongating internodes, Aust. J. Biol. Sci. 18: 781-8, 1965.

32. Summary report on field trials with gibberellic acid on sugarcane in Australia in 1968. Personal communication with Dr. J. N. Turner, Plant Protection Ltd., Fernhurst, Haslemere, Surrey, England.

33. Summer, J. B., Dinitrosalicylic acid: A reagent for the estimation of sugar in normal and diabetic urine, J. Biol. Chem. 47:5-9, 1921.

34. Sutherland, E. W., Cori, C. F., Haynes, R., and Olsen, N. S., Purification of the hyperglycemic-glycogenolytic factor from insulin and from gastric mucosa, J. Biol. Chem. 180: 825-37, 1949.

35. Wessels, J. S. C., and Baltscheffsky, H., Adenosine triphosphatase (ATP-ase) activity in chloroplasts, Acta Chem. Scend. 14: 233-46, 1960. 